Amerikastudien

American Studies (Amst)

Vormals Jahrbuch für Amerikastudien

(Formerly German Yearbook of American Studies)

Eine Vierteljahrsschrift (Published Four Times a Year)

Im Auftrag der Deutschen Gesellschaft für Amerikastudien herausgegeben von (Edited for the German Association for American Studies by)

Martin Christadler

Ernst Otto Czempiel

Eberhard Kessel

Klaus Lubbers

Jahrgang 26 Heft $3 / 4$

Volume 26 Number $3 / 4$

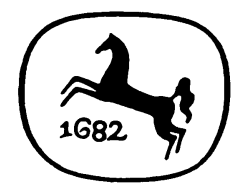

J. B. Metzlersche Verlagsbuchhandlung Stuttgart
Günter Moltmann

Bernhard Ostendorf

Klaus Poenicke

Wolfgang Viereck 
Redaktionsanschrift

Amerikastudien - Redaktion

Prof. Dr. Martin Christadler

Amerika-Institut der Universität

Kettenhofweg 130

6000 Frankfurt

ISSN 0340-2827

ISBN 978-3-476-98962-8

ISBN 978-3-476-98961-1 (eBook)

DOI 10.1007/978-3-476-98961-1

(C) 1981 Springer-Verlag GmbH Deutschland

Ursprunglich erschienen bei J. B. Metzlersche Verlagsbuchhandlung und Carl Ernst Poeschel Verlag GmbH in Stuttgart 1981 


\section{Inhalt Heft 3}

\section{Aufsätze}

Berndt Ostendorf, Ghettoliterature . . . . . . . . . . . . . . . . . . . . . . . . 259

Heinz Ickstadt, The Descent Into the Abyss: Die literarische Entdeckung des sozialen Untergrunds in der amerikanischen Fiktion des späten 19. Jahrhunderts (The Descent Into the Abyss: The Literary Discovery of the Social Underground in Late 19th Century American Fiktion) . . . . . 260

Kurt Dittmar, Jüdische Ghettoliteratur: Die Lower East Side, 1890-1924 (Jewish Ghetto Literature: The Lower East Side, 1890-1924) _ . . . . . . . . . . . . . . . . . . . . 270

Gudrun Birnbaum, Eine Stimme aus dem slowakischen Stahlarbeiter-Getto in Pennsylvanien: Thomas Bell (A Voice from the Slovak Steelworker Ghetto of Pennsylvania: Thomas Bell) . 293

Edward Paynter, Alfred Stieglitz's Machine ． . . . . . . . . . . . . . . . . . . 305

Andreas Haus, Dokumentarismus, Neue Sachlichkeit und Neues Sehen - Zur Entwicklung des Mediums Fotografie in den USA und Europa (Documentarism, New Objectivity, and New Vision - The Development of Photography in the USA and Europe) . . . . . . . . . . 315 David Seed, Penetrating America: The Method of Henry James's The American Scene . . . . . . 340

Replik (Alfred Hornung) _. . . . . . . . . . . . . . . . . . . 354

\section{Besprechungen}

Detectives and Friends: Dashiell Hammett's THE GLASS KEY and Raymond Chandler's THE LONG GOODBYE von John S. Whitley (Christine Noll Brinckmann) . . . . . . . . . . . 356 Bildergeschichten Amerikas (Reinhard R. Doerries) _. . . . . . . . . . . . . . 356 Kennedy and the Berlin Wall Crisis: A Case Study in U.S. Decision Making von Honoré M. Catudal (Knud Krakau) . . . . . . . . . . . . . . . . . . . . . . . 358 Englisches Wortgut, seine Häufigkeit und Integration in der österreichischen und bundesdeutschen Pressesprache von Karin Viereck (Hermann Fink) ． . . . . . . . . . . . . . . 361 Neuere Publikationen zur Rock-Lyrik und Rock-Musik (Christoph Bode) . . . . . . . . . . . . 367

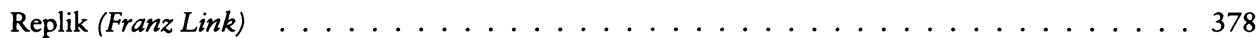

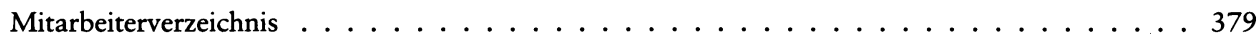




\section{Inhalt Heft 4}

Martin Christadler, Hans-Joachim Lang zum 60. Geburtstag $\ldots \ldots \ldots 38$

\section{Aufsätze}

Bernd C. Peyer, Autobiographical Works Written by Native Americans . . . . . . . . . 386

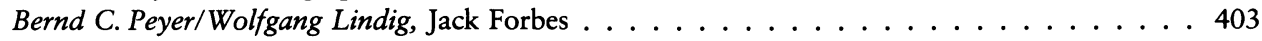

Jack D. Forbes, Determining Who is an Indian . . . . . . . . . . . . . . . . . . . . 404

Peter Bischoff/Peter Noçon, Vorurteil und Mythenbildung in der "Captivity Tale": Ein Modell für den amerikakundlichen Unterricht in der Sekundarstufe II (Versions of Myth and Stereotype in the Captivity Tale: Notes towards a Syllabus in American Studies) ～. . . . . . . . . . . 417

Irwin Yellowitz, Shorter Hours as a Response to Industrialization . . . . . . . . . . . . . . 431

Daniel Levine, Poverty and Social Security in the United States: The Progressive Years and the 1970 's . . . . . . . . . . . . . . . . . . . . . . 446

Besprechungen

Linguistic Atlas of the Middle and South Atlantic States von Raven I. McDavid, Jr. und Raymond K. O'Cain, eds. (Broder Carstensen) . . . . . . . . . . . . . . . . . 453

Studien zum Einfluß der englischen Sprache auf das Deutsche von Wolfgang Viereck (Hermann Fink) . . . . . . . . . . . . . . . . . . . . . . . 4454

Schlüsselmotive der amerikanischen Literatur von Horst Kruse (Volker Bischoff) . . . . . . . . 459

New Perspectives on the Literature of Wonder: Recent Works in Science Fiction o Fantasy Scholarship (John Dean) . . . . . . . . . . . . . . . . . . . . . 460

Beiträge zum amerikanischen Detektivroman (Jens P. Becker) . . . . . . . . . . . . . . 464

Die Rezeption Stephen Cranes in Deutschland von Friedel H. Bastein (Herwig Friedl) . . . . . . 468

Neuere Kursmaterialien zum,,westward movement" (Klaus P. Hansen) . . . . . . . . . . . . 471

\section{Bibliographie}

Ilse Repplinger, Deutsche amerikakundliche Veröffentlichungen (German Publications in American

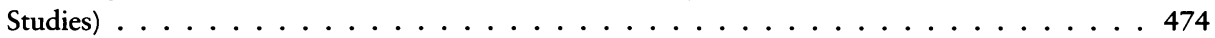

Mitarbeiterverzeichnis . . . . . . . . . . . . . . . . . . . . . . . . . 499 